\title{
OHM'S LAW: MISCONCEPTIONS OF THE STUDENTS AT SECONDARY AND SENIOR SECONDARY LEVEL
}

\author{
Yogesh Popat \\ Principal \& Teacher Physics \\ Delhi Public Elementary School, Indore, M.P, India
}

\begin{abstract}
The purpose of this study is to reveal the misconceptions towards the understating of ohm's law. The sample used consists of 40 students of class $X$ studying the Physics of CBSE curriculum. Data is collected based on essay, class room discussion and Viva-Voce. From the results of this paper it can be concluded that the students do not understands the real and actual concepts of ohm's of by merely reading the curriculum books and by performing the experiments in school lab. The results also reflect that the misconception may also arise due to the misinterpretation of language of physics in relation to electro properly. This paper is the reflection of teaching ohm's law in the classroom in which the students generally gets confused and develops the wrong concepts at secondary and senior secondary level. The results, discussion and conclusion in this paper will also help the teachers to develop the students' insight into the nature of physics.
\end{abstract}

Keywords- Ohm's law, teaching, misconception.

\section{INTRODUCTION}

Misconceptions for certain chapters in physics can be separated from the role of teachers and learners but these misconceptions can be easily reduced by following the proper way of educating as well as learning [1]. The research reflected in reference no. 2 by Bilal and Erol reflects that the students have misconceptions in understating direct and alternating current and related circuits, voltage $\&$ potential difference and its dependence on each other [2]. The field of Physics has broad areas to be studies and one of them is electricity. Majority of physics teacher starts the chapter of electricity at secondary level by directly introducing the concept of electric current which is very much in alignment with content of the text book. But the basic concepts of charges are frequently neglected which serves as a base of electricity. The delivery of the content continues with the topics like ohm's law, kirchoff's law, problem solving tactics and then evaluation. Many researches has been carried out in the field of teaching physics at Graduation level in which it is found that the students face the significant difficulties while studying the chapter electricity and more specifically ohm's law.
There are many ways, tactics, models by which one can understand ohm's law but none of them are able to explain this law in detailed and complete way. The blend of teaching methodology is required to understand the concepts and in this methodology the real practical demonstration must not be ignored although some virtual simulators are also available now day but again it develops the wrong concepts in students, if not handled and delivered properly.

In 1992 the study was conducted in which it is concluded that the majority of the students are finding it difficult to do circuit analysis by applying the basic relation of Current, voltage and resistance [3].

Following are the five things that lead to the concept of science are very difficult to understand:

(a) Concept is science is an abstract concept.

(b) Has a complex system

(c) Learner previously had limited knowledge

(d) Lack of understanding of symbols

(e) Misconception in the stud. [4]

\section{BACKGROUND}

Ohm's law serves as the very basic law of electricity given by George Simon ohm - a German physicist, in 1827. Ohm's law relates the three basic parameters of electricity - Current, voltage and resistance and this formulation may result in several other formulation and basic concepts of like conductance, resistance, current density, relaxation time etc. The basic statement of ohm's law is "Potential difference (V) is directly proportional to the magnitude of flow of current (I), provided the physical conditions remains constant". Mathematically indicated by equation (1) and there comes a constant of proportionality called the resistance of the material (R), indicated in equation (ii)

$$
\begin{gathered}
\mathrm{V} \alpha \mathrm{I} \\
\mathrm{V}=\mathrm{RI}
\end{gathered}
$$

This statement is generally taught by the teachers to the secondary level students. The experimental setup for verification of ohm's law is shown in figure (1) 


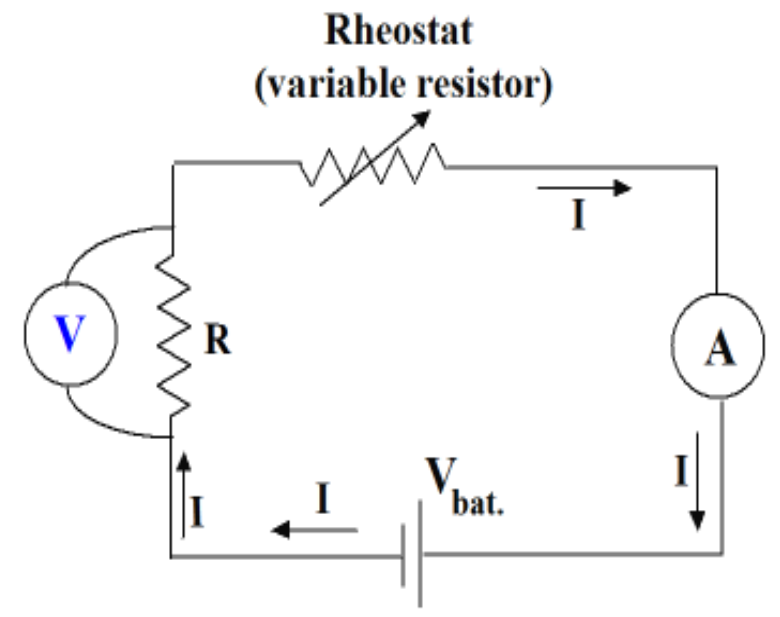

Figure 1. Experimental set up of Ohm's law [16].

Graphical representation of equation two is shown in figure 2.

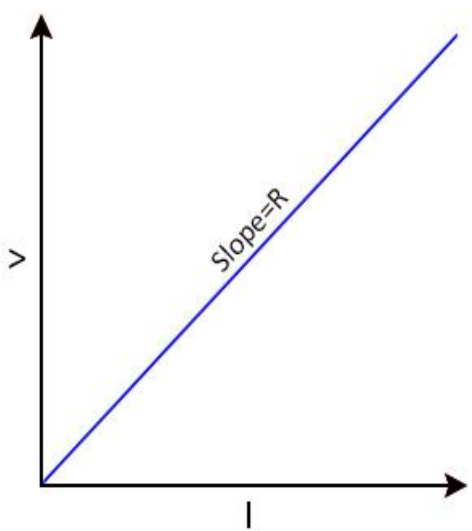

Figure 2. Linear Relation between V and I

By calculating the slope of V-I graph plotted in figure 2 gives the resistance of the material. Usually the students use the ohm's law triangle to remember the relations between $\mathrm{V}, \mathrm{I}$ and $\mathrm{R}$ as shown in figure 3.

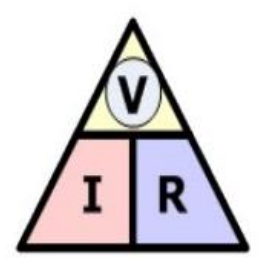

V $=I \times R$

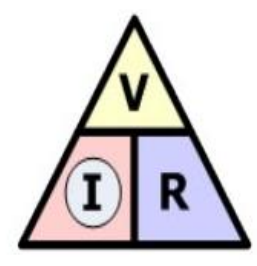

I $=\frac{V}{R}$

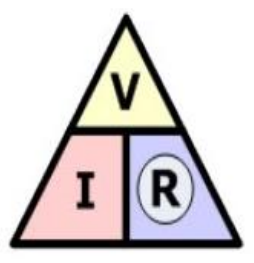

(R) $=\frac{V}{I}$
Figure 3. Ohm's Law Triangle

The relation between voltage and current can be obtained from the equation called charge conduction equation which can be written as follows

$$
\begin{aligned}
& \sigma A\left|\frac{d V}{d x}\right|=\frac{d q}{d t} \\
& k A\left|\frac{d T}{d x}\right|=\frac{d q}{d t}
\end{aligned}
$$

Equation 3 is a basic equation to deduce ohm's law which indicates the thermal conduction i.e, the rate of flow charge $\mathrm{dq} / \mathrm{dt}$ is due to temperature gradient $\mathrm{dT} / \mathrm{dx}$. $\mathrm{dx}$ represent the length of the conductor. As $\sigma=1 / \rho$, then equation 4 can be written as

$$
\frac{1}{\rho} A\left|\frac{d V}{d x}\right|=\frac{d q}{d t}
$$

Integrating both the sides of equation (5) we get,

$$
\frac{1}{\rho} A \frac{V}{x}=\frac{q}{t}
$$

In the above equation we can replace $\mathrm{x}=1$ as length of the conductor. so that in the formula symbols will have their usual meanings.

$$
\frac{1}{\rho} A \frac{V}{l}=\frac{q}{t}
$$

Now by applying basic definition of current $\mathrm{I}=\frac{q}{t}$ and resistance $R=\rho \frac{l}{A}$

$$
\frac{V}{R}=I
$$

Equation 8 indicates the basic form of ohm's law. Ohm's is applicable only to the linear elements like metal conductors and not the other elements like diodes, vacuum tubes transistors etc.

The focus of this study is on equation 8 . The study is conducted to find out the conception and misconception to the sample of students. The test includes the definitions of current, Voltage and resistance and relations of all the three parameters.

\section{RESULT AND DISCUSSION}

The result obtained in this study has been summarized in table 1 . Table 1 reflects the comparative chart between correct and wrong concepts and conception of the students. This table clearly reflects the building of misconception in relating the electrical parameters of ohm's law. Table 2 shows the percentage of students understanding the concepts of Ohm's law. An attempt has to improve the conceptions of students by providing them the practical demonstration and hands on experience of the apparatus, by teaching them using different simulators model like PHET and $\mathrm{O}$ Labs and by providing them the reference of papers listed in the reference section and further discussion on the same. After these treatments the misconception reduction has been noted in table no. 3 . 
Table 1 Students' profile towards understanding of Ohm's Law

\begin{tabular}{|l|l|l|}
\hline Correct Concept & Incorrect Concept & Student Conception \\
\hline $\begin{array}{l}\text { Current is the rate at which charge } \\
\text { flows. Current in a circuit can be } \\
\text { understood as the amount of charge } \\
\text { that passes through a wire in } \\
\text { certain period of time }(\mathrm{I}=\mathrm{Q} / \mathrm{t})\end{array}$ & $\begin{array}{l}\text { Current always appears due to the } \\
\text { potential difference found in } \\
\text { voltage source and the size of } \\
\text { current depends on voltage and } \\
\text { resistance }\end{array}$ & $\begin{array}{l}\text { Current is a flow of electron due to } \\
\text { potential difference. Electrons will } \\
\text { flow form high potential difference } \\
\text { towards low potential difference }\end{array}$ \\
\hline $\begin{array}{l}\text { The magnitude of resistance is not } \\
\text { affected by Voltage and current but } \\
\text { by the length of the conductor and } \\
\text { cross sectional area }\left(R=\rho \frac{l}{A}\right)\end{array}$ & $\begin{array}{l}\text { The magnitude of resistance is } \\
\text { varied by changing voltage and } \\
\text { current in the circuit }(\mathrm{R}=\mathrm{V} / \mathrm{I})\end{array}$ & $\begin{array}{l}\text { From R V/I, In an } \\
\text { open circuit no current will } \\
\text { appear, because the voltage } \\
\text { is equal to zero, then the } \\
\text { resistance is automatically zero. }\end{array}$ \\
\hline $\begin{array}{l}\text { (a) The magnitude of current in the } \\
\text { circuit is dependent on the } \\
\text { magnitude of potential difference } \\
\text { (b) Voltage and potential } \\
\text { difference are to different electrical } \\
\text { parameters. The Potential } \\
\text { difference is the change in } \\
\text { potential energy of the system } \\
\text { divided by the test charge. A } \\
\text { voltage is the measure of electric } \\
\text { potential difference which results } \\
\text { due to flow of electric current in } \\
\text { the closed circuit }\end{array}$ & $\begin{array}{l}\text { (a) The magnitude of electric } \\
\text { current that flows is proportional to } \\
\text { the magnitude of voltage. } \\
\text { (b) In learning electricity Potential } \\
\text { and potential difference is same. }\end{array}$ & $\begin{array}{l}\text { The current is proportional to the } \\
\text { potential difference or voltage. } \\
\text { (Considering that voltage and } \\
\text { potential difference is same) }\end{array}$ \\
\end{tabular}

Table 2 Percentage of student conception before treatment

\begin{tabular}{|c|c|c|c|}
\hline Conceptions & Category & X & XII \\
\hline \multirow{2}{*}{$\begin{array}{c}\text { Currents in a circuit can be } \\
\text { interpreted as the amount of } \\
\text { charge Q that passes through } \\
\text { the wire cross over time t. }\end{array}$} & No Conception & 55 & 40 \\
\cline { 2 - 4 } & Incorrect & 25 & 35 \\
\hline \multirow{2}{*}{$\begin{array}{c}\text { Factors that influence the } \\
\text { amount of electrical resistance }\end{array}$} & Correct & 10 & 25 \\
\cline { 2 - 4 } & No Conception & 60 & 40 \\
\cline { 2 - 4 } & Incorrect & 35 & 40 \\
\hline There is a difference between & Correct & 5 & 65 \\
\cline { 2 - 4 } $\begin{array}{c}\text { potential and voltage } \\
\text { differences }\end{array}$ & No Conception & 70 & 35 \\
\cline { 2 - 4 } & Incorrect & 30 & 0 \\
\hline
\end{tabular}

Table 3 Conceptions Before and after Treatment

\begin{tabular}{|c|c|c|c|c|}
\hline Conceptions & \multicolumn{2}{|c|}{ X } & \multicolumn{2}{|c|}{ XII } \\
\hline $\mathrm{I}=\mathrm{Q} / \mathrm{t}$ & Before & After & Before & After \\
\hline$R=\rho \frac{l}{A}$ & 90 & 15 & 75 & 35 \\
\hline $\begin{array}{c}\text { Differences between Potential difference } \\
\text { and Voltage }\end{array}$ & 95 & 20 & 100 & 20 \\
\hline
\end{tabular}




\section{International Journal of Engineering Applied Sciences and Technology, 2021 \\ Vol. 5, Issue 12, ISSN No. 2455-2143, Pages 88-91 \\ Published Online April 2021 in IJEAST (http://www.ijeast.com)}

\section{CONCLUSION}

From Table 1, 2 and 3 it can be concluded that there is a significant fall in the level and percentage of students having misconceptions towards the concept of Ohm's law. These misconceptions can be reduced by using blended teaching learning process and more importantly the practical demonstration which is considered as the heart of the science. The Students must understand the concept of electrical physics before learning further.

\section{REFERENCES}

[1]Tove C, Nina B, and Tore B, Approaches to studying: Associations with learning conceptions and preferences for teaching 2018, doi.org/10.1080/2331186X.2018.1480909 Cogent Educ 51480909.

[2] Bilal E and Erol M, Investigating Students' Conceptions of Some Electricity Concepts, Lat. Am. J. Phys. Educ. Vol. 3, No. 2, May 2009

[3] McDermott L and Shaffer, Research as a guide for curriculum development an example form introductory electricity, P 1992 Am. J. phys, 60, 994-1003. https://doi.org/10.1119/1.17003

[4]Koba S and Mitchell T C 2011 Grades 3-5. NSTA PRESS, pp. 5-6.

[5] Maloney, D. P., O’Kuma, T. L., Hieggelke, C. J. and Heuvelen, A. V., Surveying students' conceptual knowledge of electricity and magnetism, Am. J. Phys. 69, 12-23 (2001).

[6] Planinic, M., Assessment of difficulties of some conceptual areas from electricity and magnetism using the Conceptual Survey of Electricity and Magnetism, Am. J. Phys. 74, 1143-1148 (2006)

[7] Prastyaningrum and H Pratama, Student conception of Ohm's law, 2019 J. Phys.: Conf. Ser. 1321 022028, PP 1-6.

[8] Matteo Bozzi, Juliana E. Raffaghelli, Maurizio Zani. (2021) Peer Learning as a Key Component of an Integrated Teaching Method: Overcoming the Complexities of Physics Teaching in Large Size Classes. Education Sciences 11:2, 67

[9]T. Nantsou, G. Frache, E.C. Kapotis, H.E. Nistazakis, G.S. Tombras. (2020) Learning-by-Doing as an Educational Method of Conducting Experiments in Electronic Physics. 2020 IEEE Global Engineering Education Conference (EDUCON), 236-241.

[10] Tommi Kokkonen, Terhi Mäntylä. (2018) Changes in University Students' Explanation Models of DC Circuits. Research in Science Education 48:4, 753-775 